$\pm N / E$

Global Journals Inc.

की
GLOBAL JOURNAL OF HUMAN-SOCIAL SCIENCE: A

ARTS \& HUMANITIES - PSYCHOLOGY

Volume 20 Issue 20 Version 1.0 Year 2020

Type: Double Blind Peer Reviewed International Research Journal

Publisher: Global Journals

Online ISSN: 2249-460X \& Print ISSN: 0975-587X

\title{
The Ideology and Translations of the Qur'an by the Orientalists: A Comparative Study of Richard Bell's Translation
}

By Mahmoud Ibrahim Rezk Elnemr

Tanta University

Abstract- This research seeks to examine the relation between the ideology and translation; moreover, it focuses on the orientalist English translations of the Qur'an "The Qur'an: Translated, with a Critical Re-arrangement of the Surahs" by Richard Bell. The research discusses Prophet Muhammad and the historical situation of the Qur'an according to the orientalists' perspective, the origin of the Qur'an, the form, structure, and style of the Qur'an, the compilation of the Qur'an, the chronological order of Qur'anic and verses, stages of the revelation and the sources of the Qur'an, the biography of Richard Bell, features of his translation, objectives, sources, readership, motives, structure, method and the period to produce. After that, exploring the ideological effects of translation through exploring the mistranslation and misinterpretation of the translation. Lastly, Richard Bell's competence and mindset.

Keywords: ideology, translation, orientalists misinterpretation and mistranslation.

GJHSS-A Classification: FOR Code: 190499

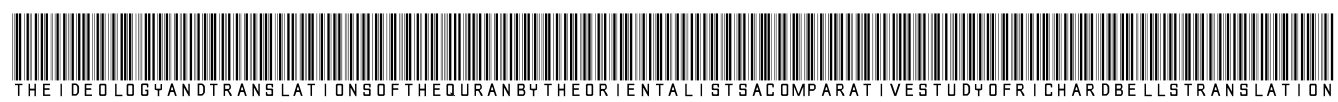

Strictly as per the compliance and regulations of:

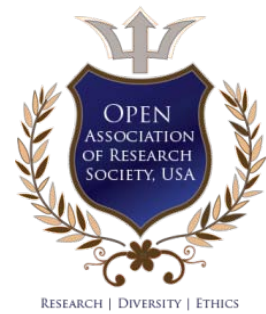

(C) 2020. Mahmoud Ibrahim Rezk Elnemr. This is a research/review paper, distributed under the terms of the Creative Commons Attribution-Noncommercial 3.0 Unported License http://creativecommons.org/licenses/by-nc/3.0/), permitting all non-commercial use, distribution, and reproduction in any medium, provided the original work is properly cited. 


\title{
The Ideology and Translations of the Qur'an by the Orientalists: A Comparative Study of Richard Bell's Translation
}

\author{
Mahmoud Ibrahim Rezk Elnemr
}

\begin{abstract}
This research seeks to examine the relation between the ideology and translation; moreover, it focuses on the orientalist English translations of the Qur'an "The Qur'an: Translated, with a Critical Re-arrangement of the Surahs" by Richard Bell. The research discusses Prophet Muhammad and the historical situation of the Qur'an according to the orientalists' perspective, the origin of the Qur'an, the form, structure, and style of the Qur'an, the compilation of the Qur'an, the chronological order of Qur'anic and verses, stages of the revelation and the sources of the Qur'an, the biography of Richard Bell, features of his translation, objectives, sources, readership, motives, structure, method and the period to produce. After that, exploring the ideological effects of translation through exploring the mistranslation and misinterpretation of the translation. Lastly, Richard Bell's competence and mindset.
\end{abstract}

Keywords: ideology, translation, orientalists misinterpretation and mistranslation.

\section{INTRODUCTION}

R ichard Bell uses the formal language and the proper equivalent for the words. He also simplified the preface that clarifies Bell's methodology in his work. Bell depends on traditional commentaries of the Qur'an e.g., Al-Baiday's work. He scrutinizes the non-Arabic vocabularies of the Qur'an. There is a particular introduction for each chapter facilitates the main points during the reading. He classifies his translation for topics and suggests a title for each group of verses. He uses the footnotes professionally to verify the meaning of some words. Sometimes he mentions different interpretations of verses in the footnote. Bell mentions the history of many verses and this is a newborn branch of Knowledge which has few references and requires a massive effort and a deep knowledge to achieve any progress in it.

Richard was born in Scotland to Christian parents in 1876. He educated at Edinburgh University, where he studies language and divinity and in Germanic Universities too. Then, he became the minister of the Church of Scotland in 1904. Then, he ordained to the parish of Wamphray in 1907. He also obtained the doctorate in divinity. After that, he returned to the University of Edinburgh for higher studies as a lecture in

Author: Independent Researcher, Faculty of Education, Tanta University, Egypt. e-mail:mahmud@naeimclearance.com
Arabic and got the position of reader in Arabic in 1938 and passed away in 1952.

Bell lived a special life which was dedicated to the church and the scholarly pursuits. Firstly, he focused on the impact of translation on Islam, structure, style, content, composition, and rearrangement of the Qur'an. The Origin of Islam in its Christian Environment was his first academic production. Secondly, he wrote seven articles which discuss various aspects of the Qur'anic studies which appeared lastly, in 1953 as The Introduction to the Qur'an, he scrutinized the verses of the Qur'an one by one, their external and internal rhymes, length, reasons of revelation, different interpretations and commentaries, its foreign words, readings of the Qur'an, history of the Qur'anic text, abrogation and abrogated verses, breaks of verses, compilation of surahs and verses, Mysterious letters, and chronological order of Surahs. He confessed that the Qur'anic structure is more complex than he thought.

\section{il. The Publication History of Bell's TRANSLATION}

Bell's translation has appeared in seven editions for 54 years with different titles. These editions are available at Washington University in the USA, Lee University in the USA, Seattle Pacific University in the USA, Library of Congress in the USA, Mc Gill University in Canada, and AUC in Egypt. Hungarian Academy of Sciences Library in Budapest, University of Pisa in Italy, and the University of Zurich in Switzerland. The first edition was published in two volumes between19371939 sequentially under the tile "The Qur'an Translated with a Critical Rearrangement of the Surahs". The second edition was published completely in 1939 with the same title of the first one. The third edition was printed in 1960 without any difference in the title. The fourth edition which completely revised and enlarged by Watt in 1970 with the different title "The Qur'an". The fifth and the sixth editions were brought out in 1980 and 1990 under the title "The Qur'an". The seventh edition has the same name of the sixth one. The last edition was issued in 1991 with a new title "A Commentary on the Qur'an". This translation is also available on online bookstores as Amazon.com and Abebooks.com. 
III. The Main Features and Structure of THE TRANSLATION

Bell as Orientalist, assumes the Qur'an is a human product and Muhammad's composition except for some verses, he received the revelation from Allah. $\mathrm{He}$ also alleges the need of the Qur'an to rearrange and divides the Qur'anic Surahs into separated units in vertical and horizontal paragraphs according to the revelation chronologically. He alters the Qur'anic text through emerging, removing, replacing and deranging the verses. Bell's translation consists of 2 volumes about 1038 pages. It has a preface of four pages which sheds light on the necessity of producing this translation, the period he spends in translating the Qur'an, objects of his translation, main sources, his method to emend the Qur'anic text, the used edition of the Qur'an as a source text, his false allegations, stages of composing the Qur'an and the rearrangement of verses and the main procedures to achieve. Bell's translation contains a table of the main 26 events in the Prophet Muhammad's life. Bell writes a note on dating and discusses Noeldeke's chronology and assumes that prophet Muhammad depended on Jewish and Christian sources. There is a list of Arabic words, names, and other phrases explained in the notes. This list contains about 160 terms in three pages; moreover, he explains the meaning of seventeen term and mentions the rest without any clarification. Lastly, there is a bibliography which refers to the most important twenty works while the full bibliography of the literature of the Qur'an which is available in The Hand Book of Islam in Pfannmüller, 1923.

\section{Bell's Theory and Hypothesis about THE QUR'AN}

His theory focuses mainly on the incoherent verses (from his perspective) which had been added later into the text. Thus, the whole text is a discrete structure as in (88:10-21). His argument that relates to these verses (88:17-21) has no connection with the previous verse, so he wonders why these verses were put here. He suggests the collectors of the Qur'an did not found any proper position except this one (Ibn Warraq 2002). So, Bell rearranged the Qur'anic text to remove any confusion in the Qur'anic text as he assumed.

Bell's main assumptions could be summarized as follows: 1-) According to chapter (53:1-18), traditions are inventions, so he alleged the prophet claimed to see Allah twice to justify his activity as a religious former. 2-) Bell assumes that Prophet Muhammad began composing the Qur'an after calming the vision in (53:1-18). 3-) According to Bell's perspective, the divine revelation does not mean the verbal communication of the text by the archangel but it is just a suggestion, and an inspiration to be able to write down the Qur'an. In the Qur'an and the Orientalists, Bell advances argument that the word "the Qur'an" is derived from the Syriac qeryana. Because of that he believed the Qur'an was suggested by the scripture readings of the Christian Church.

Bell denies all traditions (narrations-Sunnah) which associate with the sending down the revelation because of four reasons. First of all, Aisha (May Allah blessed with her), who is one of the main narrators of the traditions, was not born during the beginning of the Call, so she is not the best narrator to retell this tradition. Secondly, he relies on the weak narrations; moreover, unable to recognize the sound ones to remove any misunderstanding. Thirdly, he denies the narrations that related to the solitary stay, isolation and contemplation in the mountain of Hira. Fourthly, he presumes that Prophet Muhammad is based on the Jewish and Christian sources to borrow his religious techniques so there is less common words (ghareeb) in the Qur'an and Sunnah (Mohar 2004).

\section{The Objectives and Motives}

The main objective of the translation is to understand the deliverances of Prophet Muhammad afresh as far as possible in its historical setting. He wants the deep meaning of the interpretation, so he goes beyond the traditional commentaries. He tries to avoid the dogmatic prepossessions which frustrated the Islamic exegesis. He seeks to facilitate the grammatical structure of the Qur'an because it is considered a complicated issue for Muslim interpreters. Bell believes The Qur'an was written in different forms before the compilation whether it was written by Prophet Muhammad himself or by the companions through dictation. Thus, regarding his perspective, there is confusion in the written documents. Corrections and additions emerged into the text while passages of the Qur'an were wrongly placed and put in its unsuitable context and improper position. Therefore, Bell rearranges the Qur'anic text to solve these issues and present the coherent and simplified translation. Through his translation, Bell aims to solve the problems of the Qur'an. He seeks to explore the textual defects and the confusion in Muhammad's thoughts and style which were scrutinized by previous western writers.

\section{Bell's MAin Works}

\section{a) Books}

1- The Origin of Islam in its Christian Environment. London: Macmillan, 1926; reprint, London: Frank Cass, 1968; 2- The Qur'an Translated, with a Critical Re-arrangement of the Surahs. 2 vols. Edinburgh T. \& T. Clark, 1937-39, and 3- Introduction to the Qur'an, Language and Literature. Edinburgh University Press, 1953. 
b) Articles

1-"A Duplicate in the Koran; The Composition of Surah xxiii." MW18 (1928): 227-33; 2-"Who were the Hanifs? MW 20 (1930): 120-24; 3-"The Men of A'raf (Surah vii: 44)." MW 22 (1932): 43-48; 4- "The Origin of I'd al-Adha", MW 23 (1933): 117-20; 6-"The Style of the Qur'an." TGUOS 11 (1942-44) 9-15; 5-"Muhammad's Call" MW 24 (1934): 13-19; 7-"Muhammad's Knowledge of the Old Testament." Stadia Semitica et Orientalia 2 (1945): 1-20; 8- "Muhammad's Visions."1 MW 24 (1934): 145-54; 9-"Muhammad and previous Messengers." MW 24 (1934): 330-40; 10-"Muhammad and Divorce in the Qur'an." MW 29 (1939): 55-62; 11"Sural al-Hashr: A Study of Its Composition." MW 38 (1948): 29-42; 12-"Muhammad's Pilgrimage Proclamation" JRAS (1937): 233-44. "The Development of Muhammad's Teaching and Prophetic Consciousness." School of Oriental Studies Bulletin (June 1935): 1-9; 13- "The Beginnings of Muhammad's Religious Activity." TGUOS 7(1934-5): 16-24; 14- "The Sacrifice of Ishmael" TGUOS 10: 29-31; 15- "Critical Observations on the mistakes of Philologers". (1904): 95-118, and 16- "A Moslem Thinker on the Teaching of Religion: al-Ghazzali, A.D.1058-1111 Hibbert Journal 42 (1943): 31-36.

\section{Vil. Bell's Main Sources in his TRANSLATION}

The main sources and references he relies on, 1- Baidawi's Commentary on the Qur'an; 2- Fluegel's Edition of the Qur'an; 3- The Origin of Islam in Its Christian Environment. London: Macmillan, 1926; 4- Sirat ar-Rasul by Ibn Hisham,1858; 5- Encyclopedia of Islam; 6- Al-Itqan fi Ulum al-Qur'an by al-Suyuti; 7- The History of the Qur'an by Theodor Noldeke; 8- The Foreign Vocabulary of the Qur'an by Arthur Jeffery; 9- Christianity in the Qur'an by Ahrens, 1930; 10-Mohammed as the Founder of Religion by Ahrens; 11- The Origin of Islam and Christianity by Andrae, 1926; 12- The Life and the Faith of Muhammad, 1930; 13- Critic and Exegetic Studies about the Qur'an by Barth, 1916; 14- Translation of the Qur'an by Bonelli, Luigi, new ed. Milan, 1929; 15- The Life of Muhammad by Buhl, 1930; 16- The Aramaic Words in the Qur'an by Fraenkel, 1886; 17What Did Muhammad Receive from Judaism? by Abraham Geiger,1833; 18- Lectures on Islam by Ignaz Goldziher, 1925; 19- Mohammed by Hubert Grimme, 1892-1895; 20- Der Koran. Ausgewählt, angeordnet und im Metrum des Originals übertragen von Gubert Grimme, 1923; 21- New Researches into the Composition and Exegesis of the Qur'an, London, 1902, and 22- Qur'anic Studies by K.U.Horovitz, 1926.

\section{Vili. The Readership of the Translation}

It is important to decide the characteristics of the readership of the translated text as education, class, surrounded environment, and the dominated activity. For Bell's translation, most of the readers are educated, cultured and well-knowledge either they are western researchers and orientalists or eastern researchers and callers. For the matter of class, the majority of the readers are from the middle and high classes and have an academic degree e.g., Montgomery watt who is the student of Bell, dr. Abdullah al-Nadawi, dr. Omar Radwan, Nagieb al-Afifi, dr.abd-Aradi Muhammad, dr. Adam Bamba, and dr. Abd-al-Rahman al-Shehri. The translation has a formal style and it is difficult for the general reader to understand Bell's method, style and technique. The reader of this translation should have a background about the different branches of the Qur'anic sciences and a good level in English language to be able to recognize the main structure for Bell's translation.

\section{iX. Bell's Strategies, Methods and Techniques in Translation}

Strategies differ according to the type of the text (literary and non-literary text) and the proper techniques for texts are adaption, amplification, economy, borrowing, transposition, modulation. On the contrary, strategies are divided into literal, free, cultural and artistic. While the literal strategy refers to the translation of the target text by following the individual word of the source text. The free translation focuses on capturing the sense of longer stretches of the source text. Cultural translation focuses on matching context and artistic translation focuses on matching reactions. Dukāte (2009) also mentioned some strategies of translation e.g., being literary, non-literary, sacred texts, domestication and explication (79-131). Then in 2012, Kemppanen inserted as a translation technique. Localization also is regarded as a strategy and a cultural phenomenon. Newmark in A Text Book of Translation mentioned the difference between translation methods and translation procedures. While translation methods associate with the whole text, procedures relating to the sentences as small units of language. He suggested eight methods e.g., word-for-word translation, literal translation, faithful translation, semantic translation, adaptation, free translation, idiomatic translation and communicative translation (45-74). Newmark also proposed sixteen translation procedures to analyze the translation on the level of the sentence e.g., transference, naturalization, culture equivalent, functional equivalent, descriptive equivalent, translation label, reduction and expansion, componential analysis, synonymy, shifts or transpositions, modulation, recognized translation, compensation, paraphrase, couplets and (notes, glosses and addition) (81-91). Procedures of translation were classified as technical and organizational by Nida. Technical procedures seek to analyze the source and target languages which 
facilitate making the judgment of the semantic and syntactic approximations. Organizational procedures concentrate on the reevaluation of the text and scrutinizing the communicative effectiveness of the target text (Nida 241-247).

Bell, in his preface of the translation declares about his main procedures as alteration, substitution, and derangement. He uses the replacement in different forms e.g., rearrangement, emerging, detaching and removing the Qur'anic verses. Richard uses foreignization in translating the word of (Allah) which is mentioned 1762 times according to the concordance of abd-Al Baqi (40-75). But Bell uses the domestication technique in translating some Islamic terms which don't have the equivalent in English language e.g., (Salat) Prayer which is mentioned 63 times, (Hajj) Pilgrimage which is mentioned 11 times. He also uses the same technique during translating (Sawm) fasting. However, he does not add any note or footnote or simplified explanation for these terms. Thus, there is a shortage in using these techniques because he does not suggest the proper translation of these terms. In translating Zakat he uses foreignization and explains the meaning in the footnote but he misunderstand the meaning as he clarifies the term of Zakat "the tax which Muhammad demand from his followers for the benefit of the poor, and other purposes"(7). He also uses the footnotes to add explanation or clarifying a meaning Bell translates the names of Qur'anic Suras through transliteration and giving the English meaning alongside. But in the chapter (8) he translates "Al-Anfal" as the windfall which means "a sum of money that you receive unexpectedly or by luck" instead of "The Spoils of War". In chapters 20, 36, 38 and 50. (Ta-Ha, Ya-Sin, Sad and Qaf) he presents improper equivalents which do not transfer the sound form of separated letters e.g., (T.H, Y.S, S, and Q). In chapter (55) (Al-Rahman) he translates as The Merciful instead of The Benevolent, The Gracious or The Beneficent because there is a difference between ar-Rahman and ar-Rahim; the former is related to Allah Alone and wider than the former, while the latter may be used to describe human being and more specific and has specialty to the believers only. Bell translates chapter (90) (Al-Balad) into The Land instead of the City (Makkah) which is mentioned in this Surah. Bell uses special strategy and technique which did not use before through any translation by orientalists to rearrange the Qur'an and produce his translation.

\section{Bell's Stratigies of Verses Rearrangement}

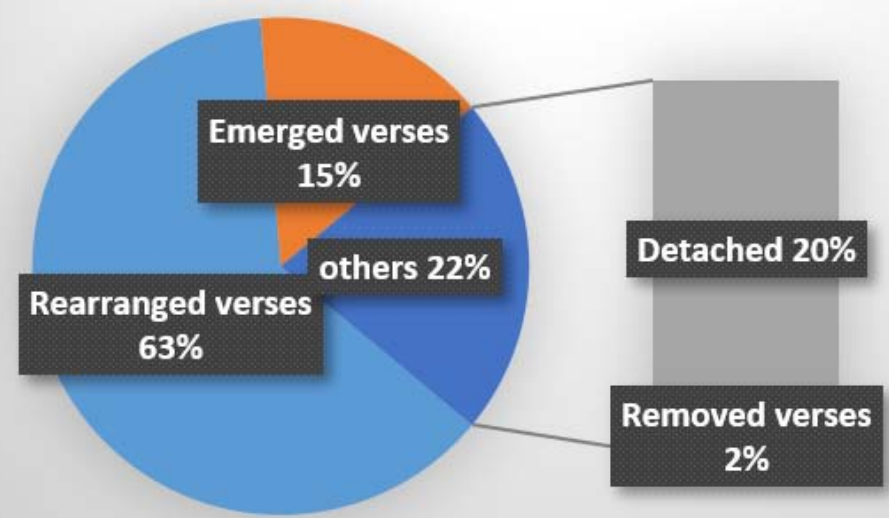

ne-arranged

Emerged

Removed

\section{Shape (A)}

\section{The Preface of Bell's Translation}

Richard Bell declares the necessity to produce a new translation and spends more than 12 years in his task. Bell considers his translation as a critical study about the Qur'an and depends mainly on The Origins of Islam. He exposes the main objects to understand the deliverances of Muhammad more closely to their historical setting. Thus, he reads classical and contemporary commentaries of the Qur'an. But he suffers from the ideological impact on these interpretations; moreover, he uses his own judgment to propose a solution and remove the difficulty of the text. The second main to unravel the composition of the separate Suras and simplify the Qur'anic text to facilitate its understanding. Bell also claims the necessity of emending the Qur'anic text and removing any difficulty by different methods. He depends on Fluegel's edition which contains a lot of errors, and the oriental writings about the Qur'an. He assumed the Qur'an was written and authored by Prophet Muhammad and his translation supplies the proofs around this point. He alleges there was a confusion in the documents which were collected to compile the Qur'an. He explores the main methods of confusion as follow: 1) interline additions; 2) additions on the margin 3) deletions: 4) substitutions; 5) pieces cut off from a passage and wrongly placed; 6) passages written on the back of 
others and read after that continuously; 7) the defects of the text because of Muhammad's own thought and style; 8) the Qur'anic Surah contains various un coherent topics; 9) the obscurity of the historical circumstances of the Qur'anic text. Bell divides the composition into three major stages. Firstly, the early period which dominated fundamentally by the sings and exhortations to the worship of Allah. Secondly, the activity of the prophet in Makkah was depended on a lot of Christian and Jewish sources. Thirdly, the composition of the Qur'an which was begun in the second year A.H. as an independent revelation. In contrast with many researchers, Bell keeps the surahs in their traditional order and rearranges the content only and this is the main procedure to remove any confusion. He does not use the chronological order because of causing complicated problems and prefers using the rearrangement of verse to achieve his objectives. Bell denies the method of Fluegel because of his division of verses, altering numbering, and broken verses accordance with internal rhymes. On the other hand, Bell uses alterations, substitutions and other derangements of the text. Bell uses the Space () in his translation to refer to the additions which had been made on the back of a scrap or scraps from elsewhere, thus he separates by lines between what precedes and follows and $(\ldots \ldots \ldots \ldots \ldots \ldots \ldots \ldots)$ to indicate that one passage was written on the back of another but there is a confusion about the collection of these verses so he uses these lines.

\section{Xi. Literature Review}

Muhammad abd-al Azeem al-Zarqani (1995) explores topics like the translation of the Qur'an and misconceptions about the Qur'an. The author writes his book in the modern Arabic language to facilitate understanding his book. Then, he refutes the misconceptions about the Qur'an. After that, he exposes the relation between Knowledge and Islam. al-Zarqani discusses the secrets of Islamic law to its magnificent. Lastly, he wants to the seeker of knowledge and callers to present the best understanding of Islam. The book contains a deep insightful knowledge about translation of the Qur'an and it also helps the translators to learn how to refute all misconceptions which will face during scrutinizing translations of the Qur'an. Abdullah Abas alNadawi (1996) examines the problems of translating the Qur'an and investigates the history of English translations of the Qur'an and evaluates seven translations. The author explores translations of the Qur'an by Ahmadiyya sect. The book provides the English translation of the Qur'an by Muslims and presents the exegesis of the Qur'an. The author exposes the main aim of the Oriental translation of the Qur'an. He also discusses the difference between the translation of the Qur'an and the translation the meaning of the Qur'an. al-Nadawi tries to refute the misconceptions of orientalists and scrutinize the misunderstanding of Qadyanism for the Qur'anic text. Yasir Qadi (1999) refers to many topics in sciences of the Qur'an through a concise method. The author evaluates some translations of the Qur'an and presents a history of the translations of the Qur'an. It is one of the earliest English books relates to the Qur'anic sciences. He used modern and classic references to produce this book and spent around four years to write the book. He left out some topics which could not be understood except in Arabic whereas some other topics did not discuss in detail because their understanding and practicality are dependent on the Arabic language. The writer tried to give the reader a general introduction to the sciences of the Qur'an. Thus, he mentioned the fundamental and important topics in detail. The book is very useful for translators of English translations of the Qur'an because it facilitates the main topics of the Qur'anic sciences to be understood. Hussein Abdul-Raof (2001) explores the translational problems and main aspects of the Qur'anic text. The author discusses the theory of translation and its practical contribution to the translation of the Qur'an. He seeks to make this book a comprehensive reference in applied translation studies. The book is useful for researchers in translations of the Qur'an and Islamic studies. Especially, the writer focuses on Qur'anic exegesis and exegetical problems. Habibeh khasravi (2016) aims to investigate the translator's religious ideology on his/ her translation of the noble Qur'an by focusing on English Translations of four verses from Surah An-Nisa(women), surah Al-Ahzab (The Confederates) and Sura an-Nur (Light) Which are mostly referred to with the aim to imagine Islam as a religion that oppresses women. Maria Perez (2016) discusses how scholars developed studies about ideology and used different tools and methods to evaluate ideology in translation studies. The book consists of nine chapters in addition to the introductory one. The writer tries to expose the main aims of the book as is the ideology different or united? How to read the ideology? The loyalty of translation and the last chapter presents the ideology and position of the translator. Zahra Ehteshami (2015) thrashes out the influence of ideology on translation, especially in the past years. It also explores two professional translators with different opposing ideologies were selected purposeful techniques to satisfy the objective of the study. Each translator was required to work on three news articles of current issues thus, the study reveals that the translator's ideology had effects on their translations. The results might be useful for curriculum developers in translation studies and practitioners. 


\section{Xil. Methodology}

The research depends on the comparative method mainly to compare "The Qur'an: Translated, with a Critical Re-arrangement of the Surahs" by Richard Bell with mainstream commentaries, doctrine, and Qur'anic sciences. The researcher seeks and discusses the ideological impact on translation and scrutinizes how the translators achieve the purpose of the source text or misrepresent it. What is the followed method? Who is the readership of the translation? It gives a selective and represents the detail of the translation with a comparison. It discusses the Suras (chapters) gradually and examines the translation of the meaning in verses that need to develop.

\section{Xili. The Case Study}

\section{a) Misinterpretation and Mistranslation}

In the following points, some verses will be discussed gradually, while others will discuss by topics. Bell claims the Opening chapter is placed at the beginning of the book by redactors, after omitting early by collectors or by Prophet Muhammad who intended it to stand as the first chapter. On the contrary, al-Qurtubi (2006) mentioned the arrangement of Surahs is obligatory according to the received revelation (98). Also, Prophet does not talk from his own inclination to place any Surah according to his perspective; moreover, Prophet Muhammad adheres to the received revelation "It is not but a revelation revealed" (4:53). He indicates that the date of sending down is uncertain and properly revealed in $2^{\text {nd }}$ year or early in $3^{\text {rd }}$ year A.H. The Majority of Muslim scholars and commentators refuted this allegation and agreed upon Surat al-Fatihah is a Makkan one and revealed in the first year of the Islamic Call, Al-Wahidi (1991) and Al-Suyuti (2006).

Secondly, in the second verse "Praise belongs to Allah the lord of World", he uses the word "Praise "which does not cover the meaning of al-Hamd, because its meaning is more comprehensive than thanking so some translators try to use all before the word while the others add the word "thanks" after the word. The suggested translation here is "gratitude". In the fifth verse "Thee do we serve, and on Thee do we call for help". He uses the biblical language especially Thee is an old religious word which means "You" the second person pronoun. He also uses the verb serve which according to the Bible is more general than worship, so any worship is a service to God but not any service is a worship. In the sixth verse, he uses the third person pronoun "Thou" instead of "They" affected by the biblical language.

Bell alleges the sixth surah is confused because it includes Makkan and Medinan verses which were sent down in different periods. He also denies the verses which relate to Abraham are not Mekkan. Bell claims the first part of the verse $(6: 108)$ is Makkan while the second one is Medinan. Ibn Kathir mentioned many narrations in his commentary that surah is Makkan and was sent down totally during one time (Vol: 3, p.215). Imam Baidawi also mentioned the surah is Makkan except for three or six verses after the verse (6:150) (Vol: 2, p153). Bell supposes that verses $(6: 1,6$, and 11$)$ are Medinan but according to all Islamic commentaries they are Makkan. Bell explains "the openings of the unseen" as "the keys of future" even there are seven interpretations for these words, there is a shortage in his explanation and the proper one is "all hidden matters". He claims "Azar" is the name of Abraham's servant name while Islamic commentaries present five opinions which explain the meaning of Azar as follows: 1) it is a name of Ibraheem's father; 2) it is a nickname of Ibraheem's father and his name is Tarikh; 3 ) it is a name for the idol and 4) it is an adjective for Tarikh which means wrong. But the preferable opinion here that Tarih is a proper name of Ibraheem's father and Azar is an adjective for him. Bell refers to the verse (6:89) in case of being Medinan, it is certainly indicating to the Jews but the verse is Makkan and refers to the disbelievers of Mekkan. Bell alleges the enemies of mankind means in the verse $(6: 112)$ to the Jews while Muslim commentaries refer to the disbelievers. Bell assumes in the verse $(6: 136)$ the prophet Muhammad used his own language not the pagans one and this is the sense that a portion is a set aside for the gods in general and then divided amongst the various deities.

Bell mentions the seventh surah is Medinan while the surah is a Makkan one except for seven verses from 163 to 170. Bell changes the Makkan verses into Medinan ones and he replaces the disbelievers of Makkan with Jews in verses $(7: 2,3$, and 4). He translates (فارع (فأل) as "the Recognition" and claims the verse $(7: 46)$ bases on Matt ,xxv,31ff while the correct meaning of the word "a wall between Paradise and fire" (al-Baidawi, vol:3, p.13). Bell in verses (7:156-157) translates (يلمزك) as "the native prophet" while the correct translation is "the unlettered prophet" because the prophet was unable to read and write. He assumes the verse $(7: 175)$ does not relate to Balaam or Umaya ibn abi-Ssalt but relates to a disobedient prophet as mentioned in the Torah (Kings Xiii). Bell removes verses $(190,191,192$, and 193).

Bell claims the ninth surah contains passages from several dates even the all verses of the surah are Medinan except two verses (9:128-129). This surah was sent down in the ninth year of Hijra. He believes verses $(1,3,7,8,13,14,17$ and 18$)$ relate to the treaty of Hudaibiyah while the verses focus on the open-ended treaty. He also mentions the intended pilgrimage was in the eighth year of hijra while the correct one was the ninth year. The meaning of () uncertain for Bell so he translates as (off hand) while the proper meaning is (submitted willingly) which means every one of the people of the book should pay his poll 
tax by his own without any attorneyship. Bell translates (كلمبي) as "point the finger at you" and this does not refer to the real meaning of the word while the close suggested words which refer to this meaning "slander or defame". As-Sadaqat in verse (9:60) means Zakat which is the third pillar of Islam not as Bell explains "the voluntary contribution of the community". Bell reconfirms that verses $(9: 96-97)$ refer to al-Hudaibiyah while the verses were sent down in the Bedouins of Asad and Ghatifan's tribe.

Bell alleges the tenth surah is a Medinan one even Muslim scholars mention the surah is Makkan except the last three verses. He also mentions that word Muslim and Hanif show that break with the Jews has already taken place He misinterpreted the verse (10:87) and claims the surah was sent down in the second and the third year after hijrah. Bell assumes the stories of the prophets borrowed from the Bible, especially the story of Moses and Aaroun. Bell alleges the verse (10:68) refers to the Christian doctrine of the divine son but the verse refers to the disbelievers who thought the angels are daughters of Allah. Bell emerged the interpretation of the verse (87) with verse (142) in chapter 2 which relates to the changing of Qibla direction. Bell indicates to the verse $(10: 92)$ was borrowed from Jewish sources e.g., (Geiger P.162).

Bell believes the eleventh surah is a Medinan one while al-Bayydawi and al-Qurtubi mention the surah is Makkan except for verse (114) which is Medinan. He describes verses (11:17-23) as a complicated piece. Bell rearrange many verses in this Surah because of the rhyme is incoherent. He also assumes verses which relate to Noah, Hud, Salih, Shuaib, Abraham and Lot stories are based on the Makkan version but with new additions; moreover, he claims the prophet Muhammad interprets verse (11:70) in hostility because the angels did not touch the food was probably a Rabbinic trait.

b) The Ideology and the Translation of The Islamic Creed

This section is focusing on Islamic beliefs which divide into three main categories. The first branch discusses translating the attributes of Allah. The second category scrutinizes the verses of the prophethood and prophets. While the third branch explores the translation of verses which relate to the unseen. We compare the verse which relate to each topic and affirm whether Bell transforms the meaning or distorts it to explore the ideological impact on these verses which associate with Islamic creed and how Bell transfer the meaning.

\section{i. The Attributes of Allah}

The main rule to know the attributes of Allah is "There is nothing like Him and He is All Hear, All Seer" (42:11). Thus, it is important to understand the verse which relates to this topic without any Ta'teel (denying the meaning), Tahreef (altering the meaning) Tashbeeh (likening Allah with others), Tamtheel (resemblance),
Takyeef (specifying the exact nature and reality) and Tajsim "embodying". So, translators of the Qur'an during this great task should avoid these previous issues to present a faithful text especially the Qur'an is not a mere book but a holy book and the word of Allah as well. The coming points will scrutinize the translation of the verses which relate to the attributes of Allah by mentioning the attribute and the verses then exploring the translation and how Bell translates them with or without the ideological impact and bases on sources in pages (14-15).

\section{ii. Istawa for Allah}

This attribute is mentioned in seven verses as follows: 1-"then seated himself on the throne" (Al-A'raf: 54); 2- "then sat firm on the throne" (Yunus: 3); 3- "then sat firm upon the throne"(Al-Ra'ad: 2); 4- "on the throne hath sat firm" ( $\mathrm{Ta} \mathrm{Ha} \mathrm{:5);} \mathrm{5-"then} \mathrm{seated} \mathrm{himself} \mathrm{on} \mathrm{the}$ throne"(Al-Furqan: 59); 6-"then sat firm on the throne" (Al-Sajdah); 7-"then sat firm on the throne"( Al-Hadid:4). Bell translates the verb "Istawa" in all verse as "sit firm" and "seat himself" while the verb refers to different meaning e.g., "ala" which means rises high, "istaqara" which means proved" , Irtafa'a which mean exalted, and "sa'eda" which means climbing up the heights. The belief of the mainstream Muslims in this point is to believe as Allah inform that He has a position over the throne. He is the One who knows the reality of this attribute (al-Istawa) so imam Malik said "Istawa is known but its actuality is unrecognized" (Fundamentals of Faith 103). Thus, the proper translation here to rise over on the throne (in a suitable manner to his Majesty).

\section{a. Throne (Arsh) and Kursi}

The throne is mentioned 21 times in the Qur'an e.g., "there is no god but $\mathrm{He}$, upon $\mathrm{Him}$ do I rely and $\mathrm{He}$ is the lord of the mighty throne" (9:129). While the Kursi is mentioned only time in "His throne is extendeth over heavens and earth" (2:255). Even there is a huge difference between the throne and Kursi, Bell does not differentiate between them and uses the same translation for both of them. According to Sunnah Kursi is just a ring if we compare to the throne. Prophet Muhammad said "The Kursi is compared to Arsh is nothing but a ring thrown out upon open space of the desert" (Al-Zahabi 306). The difference between the throne and Kursi resembles in the position, greatness, description (Arish is mentioned in detail but a few narrations about the Kursi).

\section{iii. Allah's Shin}

This attribute is mentioned only one time in the Qur'an "On the day when the leg shall be bared" (86:42). Bell uses "leg" instead of shin even there is a difference in the meaning. The former refers to "the front parts of the leg" and the latter means "is a part which is use to stand on". Bell denies the meaning of the verse and assumes this is a frequent simile which points to breaking out of the war but in the subject verse it 
indicates to the death-struggle or to the day if judgment. $\mathrm{He}$ mistranslates and misinterprets this attribute while according to the mainstream of Muslims, everyone should believe in this attribute without denying, likening, embodying, resemblance and altering the meaning because Prophet Muhammad said "Allah shall bare His Shin and then all believers men and women, shall prostrate themselves before Him but there will remain those who used to prostrate themselves in the world for showing off and for gaining a good reputation. Such a one will prostrate himself but his back will become a single (vertebra) bone (so he will not be able to prostrate) (Sahih Al-Bukhary, Vol.6, Hadith no: 441).

\section{iv. Allah's Wajha}

The word Wajha is mentioned in nine verses refer to the attribute of Allah, Allah's reward, and directing to the prayer. These verse as follows: 1-"everything is perishes but His countenance" (28:88); 2- "But the face of thy lord full of glory and honour doth endure" (55:27); 3-"and content thyself with those who call upon their lord in the morning and the evening desiring his countenance" (18:28); 4-"But only out of desire for the countenance of his lord, the Most high" (92:21); 5- "And do not drive away those who call upon their lord in the morning and the evening desiring his countenance" (6:52); 6-"that is best for those who desire the favour of Allah" (30:38), 7-"who endure patiently in desire of the favour of their lord" (13:22), 8-"We feed you simply for the favour of Allah" (76:9); 9- "Whichever way ye turn, the face of Allah is there" (2:15). The nine verses are divided into three categories. The first category involves two verses which indicate to the face of Allah as attribute while the second contains fives verses point to Allah's reward while the third type includes only a single verse which refers to "the direction of the prayer". Bell uses "countenance, favor and Face" to transform the meaning but in the first two verses which relate to the attribute of Allah he uses "countenance" which distorts and alter the meaning of the verse and its considers a form of embodying the attribute because the correct believing in the verse through avoiding Ta'teel (denying the meaning), Tahreef (altering the meaning) Tashbeeh (likening Allah with others), Tamtheel (resemblance), Takyeef (specifying the exact nature and reality) and Tajsim "embodying" thus the preferable method here for the translator to transliterate the word and clarifies the intended meaning in a footnote or between round brackets. Moreover; "countenance" comes from a French word for "behavior," but it has become a fancy term for either the expression of a face. The third, fourth and five verses their meaning refers to Allah's reword and pleasure but Bell translates as "countenance". The ninth verse refers to the direction during praying Nafilah while Bell translates "the face". Regarding the Muslim mainstream belief, we must approve this attribute to
Allah as He and His messenger approved and "there is nothing like Him" (42:11).

\section{v. Isa ibn Mariam and Christianity}

Bell claims chapter (111) is directed against Christian doctrine but it also refutes the trinity which is the main basic of Christianity. He also does not refer to Jesus in verse (19:24-29) without any explanation about his story because the declaration of tawheed (monotheism) in the following verses and confessing that he is just a servant who calls for Allah's oneness; moreover, he shall die and rise again contradict with Bell's beliefs. Bell alleges in verse $(4: 157)$ that denying crucifixion as a fabrication. He changes the position of the last words of the verse which refers to the impossibility of killing Isa "they did not certainly kill him" and gives the verse a new form and structure. He assumes in verse (3:55) that Isa is dead and Allah raises him to His self. The translator denies the meaning the verse (3:49) and the miracles of Isa to the sons of Israel; moreover, he points out that theses miracles associates with the hereafter. In page 65, he indicates that the story of Isa is resent in various ways and third chapter of the Qur'an has many assumes about Jesus because of denying it divinity.

c) Translating the Qur'anic sciences and the Ideological Impact

\section{i. The Historical Situation of the Qur'an}

Bell discusses the environment of the Arabian Peninsula and always refers to the producing of the Qur'an as a human product even this claiming is rejected by Islamic creed and denied by the mainstream of Muslims because the Qur'an is the word of Allah sent down and revealed to the Prophet Muhammad by the archangel Gabriel for 23 years. Bell explores the old empires which surrounded the Arabian Peninsula as the Persian Empire and the Byzantine Empire and illustrates their struggle to control this area. He mentions the Byzantine victory in the Qur'an (30:1-4) and how the Makkan caravans form the main links between south and north of the Arabia. Firstly, he describes the surrounded circumstances of Makkah, Madinah and the life of Bedouins. Secondly, he elucidates the Arab life and customs of tribes. Thirdly, he clarifies the position of the woman in the Arab society. Fourthly, he exemplifies the reality of sacred months and why war is not allowed to outbreak? Fifthly, he relates the different religions and gods of Arab in Mecca. Sixthly, he talks about believing in Jinn and demons. Seventhly, the relation between Arab and other religions as Christianity, Judaism and Zoroastrianism (the official religion of the Persian Empire). Eighthly, he discusses the ability of the Prophet to write and claims that the Prophet Muhammad wrote the Qur'an. Thus, he uses narrations to support his opinion that prophet Muhammad wrote after claiming 
the prophethood. On the contrast, the mainstream of Muslim scholars that Prophet Muhammad did not write or read throughout his life. Moreover, Bell misunderstood the reason of the revelation as in "And they say, Legends of the former peoples which he has written down, and they are dictated to him morning and afternoon" (25:5). Ibn Kathir refers to this misconception in his interpretation that disbelievers of Mecca fabricated this claim when they failed to face the reality of new religion. Ninthly, Bell examines the value of prophetic tradition and focuses only on Sunnah Qawliyyah (sayings) and Sunnah al Filliyyah (doings). On theother hand, he does not mention the third type of Sunnah which is Sunnah Taqririyyah (Approvals-silent permissions). Tenthly, he investigates the prophet's career and it is important to study the Qur'an to understand the personality, inspiration, claims, and purposes of the Prophet. Here, Bell uses the Qur'an as the main source to understand the life of the prophet whereas, he ignores the Sunnah which is the second source of Islam and the explanation of the Qur'an. He does not refer to the divine revelation and claims the rejection of the prophetic call according to the historical perspective. Bell alleges that the prophet claimed to be the messenger of God to his own people and town. He denies the universality of the message which stipulated in (21:107). He also thoughts that Prophet Muhammad borrowed the Qur'anic text from Jewish and Christian sources but this misconception was refuted in verses (41:2-3). He believes that Prophet Muhammad changed the direction of Prayer disgustingly because of the people of the book and this misconception was refuted also in verse (2:144). Eleventh, the writer concentrates on the character and aims of the Prophet. Thus, he claims that prophet is a religious teacher and a former. Bell believes that the tone, style and subject of the Qur'an changed according to the prophet position during the different stages of the call. He tries to scrutinize the nature of the Prophet Muhammad's inspiration but Bell alleges that prophet Muhammad was a false prophet who pretended to receive messages from God. He misunderstood the interpretation of verses (81:21) and (53:5), so he claims that Gabriel is mentioned only twice in Medinan suras even he is mentioned about eight times outspokenly in Makkan and Medinan Suras.

\section{ii. The Origins of the Qur'an}

Bell attempts to explore the theological doctrine of Islam towards the Qur'an. Then, he discusses the delivery of the Qur'an. Next, he examines the collection of the Qur'an and criticizes this collection and rises some misconceptions because of his misunderstanding of the narration which relates to this topic. Lastly, he studies the authenticity of the Qur'an. Bell does not understand the reality and the wisdom of different readings of the Qur'an, so he believes that the readings are only seven which were collected by Ibn Mujahid even the complete number is fourteen readings. In this section, Bell focuses on the different branches of Qur'anic sciences as the revelation of the Qur'an, the compilation of the Qur'an, and the readings of the Qur'an.

\section{iii. The Form of the Qur'an}

In this section, Bell explores the names of the Qur'an and mentions only the most famous three names (al-Qur'an- al-Furqan-at-Tanzil); moreover, he does not refer to the total numbers of Qur'an's name. Indeed, Muslim scholars refer to this point and mentioned most of these names. Azzarkashi mentions 55 names in his book al-Burhan fi Ulum al-Qur'an (V1:275), Fairuzabadi also mentions about 93 names, al-Nasafi points out 100 names, and ibn-Taymiyyah invokes 47 names.

Secondly, Bell investigates the division of Suras Ahzab and Parts (ajza) of the Qur'an. He scrutinizes the number of Parts, Suras, Ahzab and the heading of Suras. He searched for the secret beyond naming Suras and why and how the Suras have these names, but he failed to get it and was unable to get the references which discuss this point. While Ibn Aqiylah al-Makki explains in detail the names of Suras and why every Sura has its name and the evidence from Sunnah (2006: 374-394). On the other hand, he claimed that Suras' names were introduced by compilers who collected the Qur'an. He depends on a weak narration about Othman to clarify the reason to remove the basmallah in chapter 9 .

Thirdly, Bell indicates to the mysterious (cryptic) letters which are found at the beginning of the 29 Suras. $\mathrm{He}$ illustrates that there is not any satisfactory expiation that demonstrates the meaning of these letters. The translator ignores the narration which associates with these letters and simplified its meaning, so Ibn Aqiylah al-Makki classifies a chapter about these letters and explores the related narration (2006:254:269). Fourthly, Bell explores the division of verses (Ayat). He declares the verse divisions are not artificially imposed as the division of the Bible's verse. He also refers to the difference between numbers of verses without knowing why the companions of the prophet had various numbers of verses in their copies. Al-Suyuti in al-Itqan clarifies the different reasons and indicates all companions were agreed that the aggregate number is 6000 verses and over that they dissimilar, so some of them account the Qur'anic verses as 6000,6204, $6214,6219,6225$ and 6236 according to Ali Ibn Ibi-Talib and what is called later the Kufic numbering (2006: 443-444). Bells points out that orientalist recension by Fluegel is unlike the Kufic numbering. Fourthly, Bell sheds light upon the dramatic form of the Qur'an. He discusses the difference between the Qur'an and Sunnah (he believes that the prophet claims the revelation of the Qur'an to him and the Sunnah is his 
personal thoughts). He thinks the prophet Muhammad added few passages in the Qur'an as in (27:93) and $(26,221)$. He considers these verses were composed by the prophet because of the shifting of pronouns. He illustrates to the usage of the personal pronoun especially the third person pronoun. However, he does not refer to the shifting of pronouns.

\section{iv. The Structure and Style of the Qur'an}

Bell refers there is not any verse contains the rhymes of the poetry but only in exceptional cases, it is possible to find this type of poetic rhymes. On the contrary, most of Muslim scholars denied this type of rhymes in the Qur'an because Qur'anic text does not contain the Arabic rhymes and meters. It includes the Fasilah which is the last words of the verse and has a rhetorical meaning. Thus, there is a difference between rhyme and fasilah, the former relates to Arabic poetry and the latter is associated with the Qur'anic text only and it is a form of the Qur'anic inimitability. Az-zarkhasi (2006:56), al-Suytui (2006:1787) and Ibn Aqiylah alMakki (2006:488) scrutinize this issue in detail and all of them deny any poetic form, rhyme and style in the Qur'anic text. Bell does not explore the Qur'anic fasilah so he incited wrongly with Surat al-Ikhlas because of the last letter of the word whereas, fasilah focuses on the last word of the verse (Ayah) not the last letter. After that, he explores the internal rhymes, strophe and short pieces. The internal rhymes and strophe are not found in the Qur'anic text while the short pieces its correction should be the separated verses according to their reasons of revelation. However, there are some chapters (Suras) which were revealed completely as chapters $6,7,18,61,48$ and 77 . Bell ignores the point that some chapters were revealed completely while the reset chapters were revealed separately verses. It is important to mention here that the short pieces of the Qur'anic text helped Bell to understand the prophet's method of composition as he declares (1953:73).

Secondly, Bell indicates to the style of the Qur'an and focuses on the rhymed slogans. He seeks to discuss the simplest form of the kind in verses which begin with "say" this imperative mood mentioned 250 times in the Qur'an. He claims the passages of the prophet is similar to soothsayers' form, so the prophet uses the string of cryptic oaths. He also claimed the prophet found these random oaths are unsatisfactory, thus he used the asseverated passages as in 27 chapters. Thirdly, He mentions the dramatic scene and its main usage for homiletic purpose. The dramatic scene according to Bell's perspective that focuses on the reality of worldly life and the hereafter. Fourthly, Bell sheds light upon the narratives and parables e.g., the story of Joseph in chapter 12 and the homiletics also is main purpose. Fifthly, he discusses the simile in the Qur'an and there is a good number of similes e.g., $(21: 104)$ and (101:4). Sixthly, Bell explores metaphors in the Qur'anic text and the usage of new metaphors in the Qur'an and how the prophet borrows metaphors and words, so some words origin are foreign; moreover he accuses Muslim scholars because their lack of knowledge and they are unable to trace the origins of words but if Bell read and examined what was written about this topic in (al-Burhan: 287). But Muslim scholars e.g., Shafi, Zamkhshari, IbnFaris, IbnAtyia, abo-Almaali, Az-zarkhasi and al-Suyuti examined this point deeply and discussed the origin of the word according to their source and how Arab borrowed and used these words and how the Qur'an included these words. Abo-Baker al-wasitiy mention in his book The Guide to Recite the Qur'an in Ten Readings that "the Qur'anic text includes words were borrowed from about 50 Arabic dialects and 13 foreign languages e.g., Persian, Roman, Hebrew, Syriac, Ethiopic, Aramaic, Coptic, Greek, Indian, Nabataean, Turkish, Negro and Berber. Bell needs to investigate the Qur'anic studies references and other references which discuss this point deeply. He depends on Dr. Arthur Jeffery's The foreign Vocabulary in the Qur'an who collected in his work 250 words which had different foreign origins belong to 13 languages. The mainstream of Muslim scholars accepts the words with foreign origin because these words already were used pre-Islam and become Arabic words. On the other hand, some scholars like al-Shafi and Ibn-Jarir, who denied any foreign word in the Qur'an. Bell classified 275 words into two categories; the first one the 205 words which borrowed from other languages pre-Islam and became an Arabic word. The second category includes 70 words which have a new different usage in Arabic while 25 words were come from Syriac and Ethiopic languages, in addition to twenty-two words were taken from Hebrew and Aramaic languages and the rest were borrowed from other different languages. Seventhly, Bell comments on the language of the Qur'an because of occurring unfamiliar words and uncommon sense of the word should be clarified through explanations. Studying polysemy and knowing the less common words refute his former allegation about this point.

\section{v. The Compilation of the Surahs}

Bill asks whether the Qur'anic suras were constructed by Prophet Muhammad or by the compilers of the Qur'an. Even the arrangement of the Qur'an suras and the construction of them were obligatory and the prophet Muhammad commanded the companions to put the surahs in their current order and put the verses in its special orders in surahs. (Al-Itqan: 410).

Al-Qattan in Science of the Qur'an says "The arrangement of the verses in the surahs is a matter which is from the command of the prophet and we cannot question it (practice ljtihad in this issue). This is a matter in which there is no difference of the opinion among the Muslims (139). 
Bell in his translation rearranges the order of the verses in each Surah to remove the confusion and facilitate understanding the Qur'an. He sometimes divides the single verse to keep on the internal rhyme. Thus, he believes that verse (95) in the chapter (6) was inserted into an originally unrhymed passage in order to give it the rhyme of the Surah. What Bell alleged is certainly refuted because the prophet used to mention to the writers of the revelation to put the word in its special order according to the divine revelation. Bell gives duplicated number for verses which are related to the same topic e.g., 19a and 19b for verses 20 and 21. He does not change the order of verses only but change the content of the verse to avoid any contradiction or confusion and misunderstanding of the Qur'anic text as he claims in his preface $(3: 137)$. Bell emerges two verses to become one verse e.g., 1, 2, 40 and 41 in chapter 2. During the translation, he divides the verse into separated passages and inverts the first part to be the second and vice versa e.g., (2:19). Moreover, Bell rearranges the verses 139,140 and 141 and inserts 136,137 and 138 in their places because the former has a detached theme so he replaces the verses to present coherent themes and avoid any contradiction. The translator divides the only single verse of the Qur'an into two verses in his translation e.g., verse 142 in chapter 2 divides into (137-138). Bell splits the verse 144 into (139a-139b) because of the hortatory purposes so he changes around the verses as follows 144 (139a), 145, 146, (139b). Bell does not enumerate verses $(273-277)$ and blend them into other verses (272, 275 and 276). In the third chapter, he merges the first half of the fourth verse into the second verse and detached the second half as a verse. For the first time, he splits (3:7) into four quarters and alleges the last third connects with the second verse. He amalgamates three verses together to form averse with separated unarranged parts e.g., (3:51-49-50) to form (44c-44a-44b). He removes some verses of Surahs e.g., chapters (2:155-160), (5:116120), (7:189-192) and (39:75). Bell also changes the numbering of 15 chapters, rearranges 611 verses, emerges 149 verses and removes 20 verses. Table (2) clarifies the focal points of Bell's rearrangement theory in his translation of the Qur'an. The translator claims there are many passages which could be detached without revealing the older rhyme underneath. He alleges short explanations occasioned by obscurity were written by some later reader e.g., (6:21) and (7:90). He also refers to the explanation which was added in the form of extension of the passage and this case is found in 12 verses in the Qur'anic text as in (101:7) and (104:5). The following table clarifies the verses which were rearranged, emerged in other or detached from others and the deleted ones.

\section{PROBLEMS OF TRANSLATING the QUR'AN}

English and Arabic languages belong to different families of languages, so Nida refers to that there are not two matched languages in the meanings, phrases and sentences (2000: 126). Translators of the Qur'an face different types of problems on linguistic level or on other levels thus this section tries to scrutinize the problems and how Richard Bell solve it.

\section{a) The Lexical Problems}

\section{i. The Lexical Ambiguity}

It is one of the main obstacles in religious text and there are about 700 lexical and syntactic ambiguities in the Greek Gospels. However, Richard mentions that obscurity of the historical circumstances is the main reason beyond this type of ambiguity. Asim llyas divides the lexical ambiguity into two main categories, the denotational indeterminacy and Homonymy. For indeterminate denotational, Bell translates "Gasaq" which is mentioned twice in (38:57) and (78:25) as tears and adds in the footnote that the meaning is uncertain. Commentators clarify the meaning of the word as pus, very severe cold and intolerable cold liquid. Bell depends on Baidawi commentary but he misunderstood the passage and transformed the wrong Quotation. The word may translate as pus, dirty wound charges or purulence. He also in the chapter (83:27) does not suggest any translation for the word Tasmin except transliterate it and mention the meaning is obscure and unknown, however, commentators simplified its meaning i.e. a spring in paradise and the best water in paradise which descend from above". Thirdly, Bell refers to the word "Hiita" in chapter (2:58) that the word is borrowed from the Hebrew language and the reference is vague but some reminiscence of the attempt to enter the Promised Land at Kadesh. On the contrary, the Old Testament interprets the meaning of the word e.g., "flour or the brown powder" this, alFara points to its Nabataean source (Al-Muarab 198). The suggested translation for this word is "Forgive us". Fourthly, He mentions in (2:256) that Taghut is a foreign word borrowed from Ethiopic language and means in "idols". But on the other hand, al-Suyuti in Al-Muhazab indicates to the narrations about Ibn-Abbas and AlTabari which refer to the meaning of Taghut in the Ethiopic language as "clergyman and the Satan" (81).

\section{ii. The Lexical Gap}

The Lexical gap is defined as "A hole of pattern that refers to the absence of a lexeme at a particular place in the structure of a lexical field" (Al-Utbi 2011). The affirmative verb (د) (د) mainly refers to the approximation to the occurrence of an action realized in the form of an imperfect indicative form of the verb. Moreover, the negative particle may add to the verb and this effect on the meaning of the sentence. Bell 
translates the verb correctly in the coming verse because of using an adverb nearly which refers to the close the meaning of the verb "after the hearts of some of them had nearly swerved aside" (9:177). He uses also adverb almost in "she had almost revealed him" (28:10) which transforms the meaning accurately. The translator uses "almost and nearly" to express the affirmative meaning of the verb in (2:15), (67:8), (24:34), (22:72) and $(7: 150)$. Bell uses "hardly" to express the negative meaning of the verb which is mentioned in (2:71), (14:17), (43:52) and (18:93).

\section{b) Polysemy Problems}

Polysemy as a concept means "the word which has a set of different meanings" (Palmer 100). Ullman also defines it in Semantics "the situation" in which the same word has two or more different meanings (159). Here we try to explore how Bell translates this phenomenon. Bell translates the word "Ummah" in "Verily Abraham was a community" (16:120) and points to the meaning of the word in this verse is similar to (2:128 and 141). While Ummah means in the former verse "a religious leader who possess goodness or a guider" but in later verses refer to a group of people or nation (Al-Askary 34). Ibn al-Gahwzi mentions five meanings of the word and al-Askary adds the other five meanings. Bell also translates Ummah as a community in "The people were one community" while it means here have the same religion. In "Verily this community of yours is one community" (21:92) while the first means sharia, the second means a religion. The translator should take the context into consideration to solve this problem. The translator transforms the meaning of the word "Libas" in "but the garment of the piety is better" (7:26) while the word means "the righteous deeds". But he translates it correctly in "O people of the book do not confuse the truth with the false" because it means here to mix mingle. Bell translates "Thyiab" as a garment in "Thy garment purify" (74:4) while it means "the heart". The word "Istighfar" has three meanings in the Qur'anic text. The first is the repentance but Bill translates it in "Ask pardon your lord" (71:10). The second is the "Salah" Prayer i.e. "nor Allah going to punish them while they were asking pardon" (8:33). The third is seeking forgiveness and this is the basic meaning of the word as "ask pardon for your sin" (10:29). The word "Al-Ard" the earth has nine meanings and we are going to focus on the main ones. The first is the paradise but Bill translates it in "Inherit the earth shall my servant the righteous" (21:105). The second is al-Madinah "Lo, My land is wide" (26:56). The third is Makkah as in "We were oppressed in the land" (4:97). The fourth is Egypt in "Set me over the store-houses of the land" (12:55). The translator of the Qur'an should exert his best effort to explore the different meanings of the word in different verses and solve the faced problems.

\section{c) The Culture Problems}

The translator should be aware of the cultural expressions during translating the sacred text especially and one of the main problems which face him. Bell tries to translates the word "diya" in "if anyone kills a believer by mistake, the penalty is the sitting free of a believing slave" (4:92). Arabs before Islam lived within tribes and the relationship among tribes is controlled by their customs but after Islam, they were controlled by Islamic law which saves and appreciates the life of mankind. Thus, diya should be paid for the family of murdered Muslim who was killed by mistake. This term challenges the translator to replace it, so Bell uses the penalty to express the meaning while it does transform the required meaning completely. Diya is not only a penalty but it is also a penance from the committed deed. This term requires more clarification in translation; moreover, Bell does not simplify it in a footnote or transliterate it. The second word is the "Jizyāh" which occurs in "until they pay the jizya off hand" (9:29). Jizyah is a limited portion of payment on non-Muslims who live under the banner of Islam. The translator tries to close the meaning to the readership through transliterating it but in the footnote, he clarifies the meaning as a tribute and a poll-tax. The translated equivalent and its clarification do not reflect the accurate meaning of the term because there are not any references to the excuses cases and its little portion and why it is collected, who pay it and when? Thirdly, "Muhajirin and Ansar" which is mentioned in "Those who have precedence are the first of al-Muhajirin and al- Ansar" (9:100). The earlier Muslims migrated from Makkah to Madinah in 622 A.D to establish the new state and civilization that lead the world after a few years. The translator here transliterates the two words without any explanation for the readership or clarifying the difference between the two words. While the first refers to the Makkan migrators and the latter points to the Medinan helpers. The translator should do his best to facilitate the culture-bound expressions for the readership to portray the cultural expressions which reflect the total behavior of the society. Fourth word is Lailatu al-Qadr which occurs in "Lo, we have sent it down on the night of power" (97:1). This night occurs during the last third of Ramadan especially on odds nights when the Qur'an was revealed for the first time. Bell translates it "the night of power" which refers to the "Quadra" i.e. the power and ability thus, he replaces it wrongly. The proper equivalent here is "the night of decree" because therein all matters for the next year are decreed. Moreover, he mentions in the footnote that the original text of the Qur'an is lost.

\section{Translator's Competence}

The translator should develop different aspects of his competence i.e. language competence, textual 
competence, subject competence, cultural competence and transfer competence. Transferring the meaning depends basically on the former four types to achieve the goal of the message. Language competence is not only contrasting two languages but the ability to use SL and $T L$ as a mother tongue with different skills in addition to the knowledge of the terminology, morphology and syntax. Textual competence depends on the translator's ability to know the norms of ST and $\Pi$ and their subdivision. The translator also should know the linguistic and extra- linguistic features of the text. Subject competence focuses mainly on the highly specialist knowledge's branch. It is not important to be active knowledge but the translator must know the ways and means of how to access this when they need it (Adab 9). For cultural competence means the ability to differentiate between text types with their cultural embeddedness. Thus, the translator is an intercultural competent through combining the elements of different cultures in his mindset. Integration is rejected but respecting other cultures is required. Transferring competence is the cornerstone in translation so the knowledge and the ability to use the strategies of translation, method of transforming and procedure of converting should be mastered. Bell's language competence has a shortage in lexical and semantic aspects because the translator should be able to cover different contrastive linguistic issues. He depends mainly on dr. Jeffrey's the Foreign Vocabulary of the Qur'an and does not refer to linguistic matters in SL and $\mathrm{TL}$. For the textual competence of Bell, he denies the holiness of the Qur'an by calming its human production thus he alleges the confusion of the Qur'anic text and rearranges the verses to solve the related contradictions. He refers to ten branches of knowledge in his translation while the branches associate with the Qur'an according to ibn-Aqilah al-Makki are 154 barmches. Thus, Bell has the ability to compare between commentator and meaning of non-Arabic words; moreover, he explores the bibliography of the prophet deeply and mentions battles and events dates and associated situations. For cultural competence he has a little shortage relates to some verses but in many positions, he crosses these issues by clarification footnotes. Finally, Bell's transferring competence depends on the previous ones, so it has a shortage of linguistic, cultural, textual aspects but he approximately masters the subject. However, the ideological impact effects on this knowledge mainly.

\section{The Results}

Richard Bell is an orientalist who translates the Qur'an and the ideological impact dominated his work. $\mathrm{He}$ misclassifies the Sunnah and denies its rule in Islamic law and considered it a composition of the prophet. Bell depends on the Qur'an as the main approach to understand the prophet's life without referring to prophets says even Sunnah is considered an explanation of the Qur'an. He misuses the reasons of the revelation thus he presents an improper interpretation of the verses. Richard denies the universality of the Islamic message and Prophet Muhammad was a messenger for his people only. He also assumes that the prophet depended on Jewish and Christian sources for thirteen years. Bell affirms that Qur'an is a human product except for some verses revealed and the prophet composed the Qur'an in Madinah so there is not any complete Makkan surah in the Qur'an. He refers to the prophet's ability to read and write then discuss the falsehood of the prophetic message. According to his claim, the prophet did not meet the archangel except twice only. He denies the meaning of verses which refer to the revelation of the Qur'an. There are some issues in the Qur'anic sciences he does not get it e.g., why some surahs are long while others are short? Why the style of the short surahs is stronger than the long ones? Why the numbering of the Qur'an is different from school to another? Bell denies the holiness of the Qur'an and Sunnah; moreover, he alters the total numbering of some chapters e.g., (27) and removed some verses of chapters e.g., (5). Richard denies different types of revelation and the rearrangement of surahs was by companions. He approves only seven readings only of the Qur'an and does not refer to the rest. The cryptic letters do not have any explanation in twenty-nine chapters. He uses four strategies to rearrange the verses of the Qur'an. The translator tries to arrange the target text according to its rhymes. Bell refers to foreign vocabularies of the Qur'an but he wrongly mentions their sources. He denies the ignorance of Muslim commentators about this issue. He misinterprets the abrogation and abrogated verses. He mentions that the history of some verses is unknown or uncertain. Bell points the meaning of some verses is uncertain especially verses which relate to the scientific inimitability of the Qur'an. Bell denies some Qur'anic stories (2:257-258); moreover, he denies the content of some verses e.g., (290-259). He does not clarify the meaning of some Islamic terms and the meaning of others is confusing.

\section{The Conclusion}

Even ideological impact is clear and dominated in most of the chapters, the main pitfalls of Bell's translation are as follows: the rearrangement of verses which causes many difficulties for the readership. This translation requires a high level of knowledge in Islamic studies to get it. The less common word and polysemy cause many difficulties for Bell. He focuses on some branches of the Qur'anic branches without others. Changing the meaning and denying the inimitability of the Qur'an. Altering the intended meaning during 
translation. Distorting the mains aspects of Islam and the Qur'an. Containing weak and odd opinions in translation. The translation has many mistranslated and misrepresented verses. Bell applies some branches of the Qur'anic sciences wrongly. The translation contradicts with Islamic creed. The translator has a theory about the revelation of the Qur'an and applies it during translation. The wrong sorting of chapters as Makkan or Medinan. Changing the numbering of chapters, deletion of verses, detaching some verse and emerging others. The translation is suitable for a special level of readers and it is not available in the Middle East except online or in the AUC's library in Egypt.

\section{References Références Referencias}

\section{A. English References}

1. Al-Amri, Waleed Bleyhesh. THE LUMINOUS QUR'AN. 1st ed., Madinah, KSA, Endowment for Cherishing the Two Glorious Revelations, 2019.

2. Al-Azzam, Bakri, and Mohammed Al-Ahaydib. "Cultural Problems in the Translation of the Qur'an." International Journal of Applied Linguistics and Translation, vol. 1.2, 2015, pp. 28-34.

3. Ali, Abobaker, and M. Alsaleh Brakhw. "Transferring Polysemic Words from Arabic into English: A Comparative Study of Some Samples from the Holy Quran." Aust J Basic App/ Sci, no. 8.23, 2012, pp. 38-43.

4. Bell, Richard, and W Montgomery Watt. Bell's Introduction to the Qur'an. Edinburgh, United Kingdom, Edinburgh University Press, 2015.

5. Carroll, Robert P, and Stephen Prickett. The Bible: Authorized King James Version. Oxford; New York, Oxford University Press, 2008.

6. Collins Cobuild Dictionary. S.L. Collins, 2001.

7. El-Khatib, Abdallah. A Critical Study for the Proper Methodology for Translating Islamic Terms in the Holy Qur'an into English: With Special Reference to Some Qur'anic Terms. KSA, The Symposium of Translation the Meaning of the Qur'an, 2002.

8. Elkhatib, Ahmed Shafik. Studies in the Language of the Glorious Qur 'añ. Cairo, Dar Al-Salam, 2005.

9. El-Sayed, Ramadan Hassan Ahmed. A Functional Approach to Rendering Some Selected Anthropomorphic Images in the Qur'ân into English. Diss. Helwan University, 2017.

10. Ghadhalah, H.S. "Translating Islamic Terms." The Symposium of Translationg the Meaning of the Qur'an, 2002.

11. Herrag, El-Hassane. The Ideological Factor in the Translation of Sensitive Issues from the Quran into English, Spanish and Catalan. Spain, Universitat Autònoma de Barcelona, 2012.

12. Ilyas, Asim Ismail. Linguistic and Extra-Linguistic Problems in the Translation of the Holy Qur'an Diss. University of St Andrews, 1981.

13. Jeffery, Arthur. The Foreign Vocabulary of the Qur'an. Leiden - Boston Brill, 2007.

14. Khalifa, Mohammad. The Sublime Qur'an and Orientalism. Longman, p. 1983.

15. Khosravi, Habibeh. "Influence of Translator's Religious Ideology on Translation: A Case Study of English Translations of the Nobel Quran." International Journal of English Language \& Translation Studies, no. 4.4, 2016, pp. 151-163.

16. Saeed, Abdullah. Interpreting the Qur'añ: Towards a Contemporary Approach. London, Routledge, 2006.

17. Schaffner, Christina, and B J Adab. Developing Translation Competence. Amsterdam, J. Benjamins Pub. Co, 2000 .

\section{B. Arabic References}

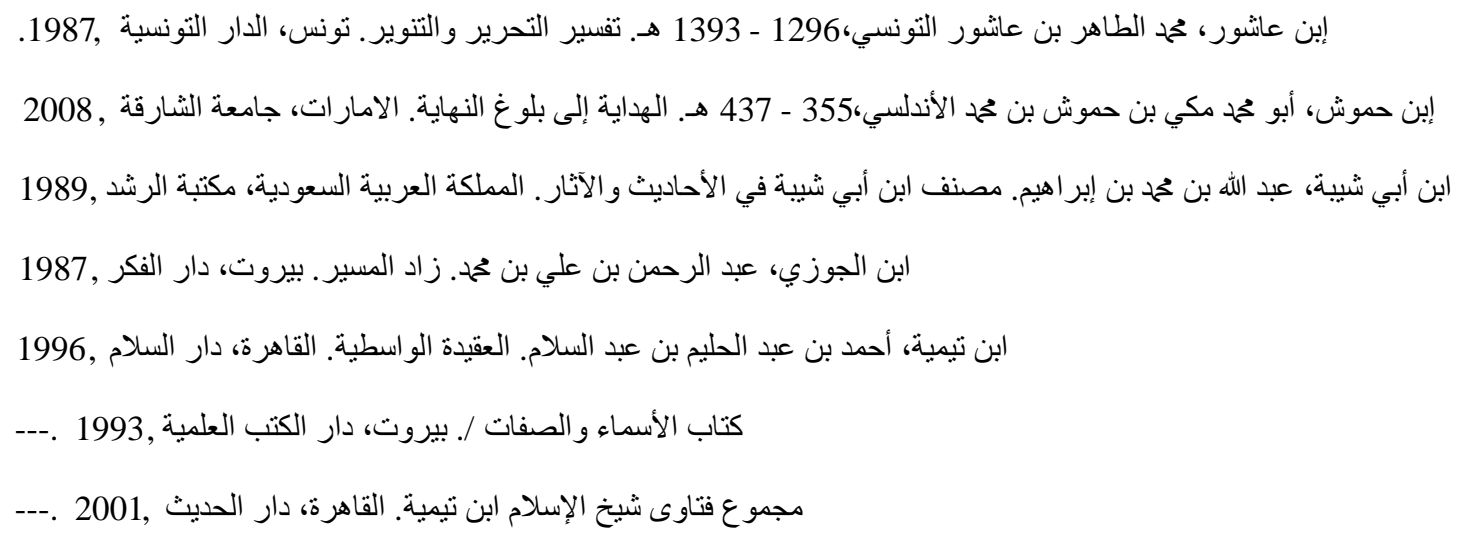


1983, ابن جرير الطبري، تحمد بن جرير بن بزيد. تفسير الطبري من كتابه جامع البيان عن تأويل آي القرآن. بيروت، دار المعرفة

2005, ابن عبد البر، يوسف بن عبد الله بن محم. الأجوبة المستو عبة عن المسائل المستغربة من صحيح البخاري /. القاهرة، دار ابن القيم للنشر

1995, ابن كثير، إسماعيل بن عمر بن كثير. تفسير ابن كثير: تفسير القرآن العظيم. بيروت، دار الكتب العلمية

2003, ابن منظور، محمد بن مكرم بن علي. لسان العرب. القاهرة، دار الحديث

1990, ابن هثام، عبد الملك بن هثام بن أيوب. السبرة النبوية لابن هشام. بيروت، دار الكتاب المصري

1970, الألوسي، محمود ابن عبد الله، 1802-1854. روح المعاني في تفسير القرآن العظيم و السبع المثاني. القاهرة، ادارة الطباعة المنيرية

2002, البخاري، محم اسماعيل. صحيح البخاري. دمشق، دار ابن كثير

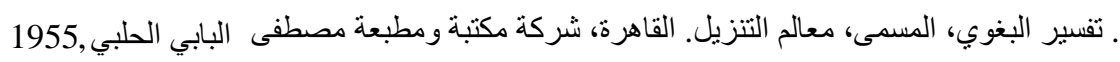

البغوي، الحسين بن مسعود بن محم، الخازن، علي بن محمد بن إبر اهيم

1996, البيضاوي، عبد الله بن عمر بن محم. تفسير البيضاوي /.بيروت، دار الفكر

1986, البيهقي، أحمد بن الحسين بن علي. أسماء الله وصفاته المعروف بالأسماء و الصفات. المملكة العربية السعودية، دار السواد

1997, الثعلبي، احمد بن ححمد ابو إسحاق، م. هب • 1. الكثف و البيان: المعروف تفسير الثعلبي. بيروت، دار احياء التراث العربي

2003, الجلال السيوطي، عبد الرحمن بن أبي بكر بن ححم. الإتقان في علوم القرآن. بيروت، دار الفكر

المهذب فيما وقع في القرآن من المعرب. المغرب، صندوق إحياء التراث ,--. 1989

الر اغب الأصفهاني، الحسين بن خحم.، هيثم خليفة. المفردات في غريب القرآن /. بيروت، دار الفكر ,1973

1993, الزرقاني، محمد عبد العظيم. مناهل العرفان في علوم القرآن. القاهرة، دار الحديث

2010, الزركثي، محد بن بهادر بن عبد الله. البرهان في علوم القرآن /. القاهرة، دار الحديث

2009, الزمخشري، محمود بن عمر بن محم. تفسير الكثاف عن حقائق التنزيل وعيون الأقاويل في وجوه التأويل /. بيروت، دار المعرفة

2003, العسقلاني، احمد بن على بن حجر. فتح الباري بشرح صحيح البخاري. القاهرة، دار الصفا

2003, القرطبي، ححمد بن أحمد بن أبي بكر. الجامع لأحكام القرآن، أو، تفسير القرطبي. بيروت، دار الرسالة

1990, القطان، مناع خليل إسماعيل. مباحث في علوم القرآن /. بيروت، مؤسسة الرسالة

1981, القيسي، مكي. الكثف عن وجوه القراءات السبع و عللها وحججها /. بيروت، مؤسسة الرسالة

1992, الماوردي، علي بن ححمد بن حبيب. النكت و العيون، أو، تفسير الماوردي /. بيروت، دار الكتب العلمية

1991, الو احدي، علي بن احمد، م 1076. اسباب النزول. القاهرة، مكتبة المتنبي

2001, بلاسي، حمح السيد علي. المعرب في القرآن الكريم: در اسة تأصيلية دلالية. بنغازي، ليبيا، جمعية الدعوة الإسلامية

2006, عقيلة المكي، محمد بن أحمد بن سعيد، الزيادة والإحسان في علوم القرآن /. الثارقة، الإمار ات العربية المتحدة، جامعة الثارقة، مركز البحوث و الدراسات

1991, عبد الباقي، محمد فؤاد. المعجم المفهرس لألفاظ القرآن الكريم /. القاهرة، دار الحديث

2003, قاسمي، جمال الدين. تفسير القاسمي: المسمى محاسن التأويل. الجزء السابع. بيروت، دار الكتب العلمية

ناشُون مسلم بن الحجاج القشيري، صحيح مسبم وهو المسند الصحيح المختصر من السنن بنقل العدل عن العدل، عن رسول الله بيروت، موسوعة الرسالة. 